\title{
The International Society for Complementary Medicine Research
}

\author{
Max H. Pittler \\ Complementary Medicine, Peninsula Medical School, Universities of Exeter and Plymouth, Exeter, UK
}

The International Society for Complementary Medicine Research (ISCMR) is a scientific organization of researchers, practitioners and policy makers that fosters complementary and integrative medicine research and provides a platform for knowledge and information exchange to enhance international communication and collaboration. The increase in the prevalence of CAM use over recent years in many countries (table 1), called for an international society to pool common research interests and efforts. ISCMR was established on November 22, 2003 at Exeter's 10th Annual Symposium on Complementary Health Care held in London, UK. Since then it has rapidly grown into one of the main societies in complementary medicine and now has members from 14 different countries. The Society's aims are to:

- facilitate communication and collaboration among researchers and practitioners

- provide access to relevant events, conferences, publications and funding opportunities

- provide access to an international database of ISCMR members

- facilitate collaboration with researchers, societies and professional organizations

- organize an annual complementary medicine research conference
Thus, while other societies represent their specific therapy, the uniqueness here is that a forum is provided for the entire breadth of complementary medicine. This has a number of advantages ranging from easy access to information of members from different areas of complementary medicine to increased possibilities of interdisciplinary research collaboration and enhanced lobbying power. Joint action to put pressure on relevant bodies to increase funding is perhaps the single most important point to secure high-quality future research into evidence-based complementary medicine.

Other benefits to members include reduced conference admissions and reduced subscription fees to journals:

- Research in Complementary and Classical Natural Medicine (Forschende Komplementärmedizin und Klassische Naturheilkunde)

- Focus on Alternative and Complementary Therapies (FACT)

- Evidence-based Complementary and Alternative Medicine (eCAM)

- Journal of Alternative and Complementary Medicine (JACM)

- Complementary Therapies in Medicine (CTIM)

- Natural Standard Monographs

- Journal of Herbal Pharmacotherapy
Table 1. Recent 1-year prevalence data of CAM use in representative general population samples

\begin{tabular}{lllll}
\hline $\begin{array}{l}\text { First author } \\
\text { Reference }\end{array}$ & Country & $\begin{array}{l}\text { Year of publication / } \\
\text { sampling }\end{array}$ & Sample, $\mathrm{n}$ & $\begin{array}{l}\text { Prevalence, } \\
\%\end{array}$ \\
\hline Härtel [1] & Germany & $2004 / 2002$ & $\begin{array}{l}\text { representative } \\
1,750\end{array}$ & 62.3 \\
Thomas [2] & United Kingdom & $2004 / 2001$ & $\begin{array}{l}\text { representative } \\
1,794 \\
\text { representative }\end{array}$ & 10 \\
Shmueli [3] & Israel & 2004/2000 & $\begin{array}{l}2,505 \\
\text { representative }\end{array}$ & 62 (incl prayer) \\
Barnes [4] & United States & 2004/2002 & 31,044 & \\
& & &
\end{tabular}

\section{KARGER}

Fax +497614520714

(C) 2005 S. Karger GmbH, Freiburg

www.karger.com
Max H Pittler MD PhD

Complementary Medicine, Peninsula Medical School

Universities of Exeter and Plymouth

Exeter, United Kingdom

E-mail M.H.Pittler@exeter.ac.uk 
For more information please go to www.iscmr.org or contact ISCMR 715 E. Huron Street, Suite 1E, Ann Arbor, MI 48104-1555, USA, Phone: +1 734 998-7715, Fax -7720, E-mail info@iscmr.org.

\section{References}

1 Härtel U, Volger E: Use and acceptance of classical natural and alternative medicine in Germany - findings of a representative population-based survey. Forsch Komplementärmed Klass Naturheilkd 2004;11:327-334.

2 Thomas K, Coleman P: Use of complementary or alternative medicine in a general population in Great Britain. Results from the National Omnibus survey. J Public Health (Oxf) 2004;26:152-157.

3 Shmueli A, Shuval J: Use of complementary and alternative medicine in Israel: 2000 vs. 1993. Isr Med Assoc J 2004;6:3-8.

4 Barnes PM, Powell-Griner E, McFann K, Nahin RL: Complementary and alternative medicine use among adults: United States, 2002. Adv Data 2004;343:1-19. 